Louisiana State University

LSU Digital Commons

3-1-2012

\title{
Tropical tree seedling growth responses to nitrogen, phosphorus and potassium addition
}

Louis S. Santiago

University of California, Riverside

S. Joseph Wright

Smithsonian Tropical Research Institute

Kyle E. Harms

Smithsonian Tropical Research Institute

Joseph B. Yavitt

Cornell University

Carmi Korine

Ben-Gurion University of the Negev

See next page for additional authors

Follow this and additional works at: https://digitalcommons.Isu.edu/biosci_pubs

\section{Recommended Citation}

Santiago, L., Wright, S., Harms, K., Yavitt, J., Korine, C., Garcia, M., \& Turner, B. (2012). Tropical tree seedling growth responses to nitrogen, phosphorus and potassium addition. Journal of Ecology, 100 (2), 309-316. https://doi.org/10.1111/j.1365-2745.2011.01904.x 


\section{Authors}

Louis S. Santiago, S. Joseph Wright, Kyle E. Harms, Joseph B. Yavitt, Carmi Korine, Milton N. Garcia, and Benjamin L. Turner 


\section{UC Riverside \\ UC Riverside Previously Published Works}

Title

Tropical tree seedling growth responses to nitrogen, phosphorus and potassium addition

Permalink

https://escholarship.org/uc/item/5mw387pz

Journal

journal of ecology., 100(2)

\section{ISSN}

0022-0477

\section{Authors}

Santiago, Louis S

Wright, S Joseph

Harms, Kyle E

et al.

Publication Date

2012-03-01

\section{DOI}

10.1111/j.1365-2745.2011.01904.x

Peer reviewed 


\title{
Tropical tree seedling growth responses to nitrogen, phosphorus and potassium addition
}

\author{
Louis S. Santiago $^{1 *}$, S. Joseph Wright ${ }^{2}$, Kyle E. Harms ${ }^{2,3}$, Joseph B. Yavitt ${ }^{4}$, \\ Carmi Korine $^{5}$, Milton N. Garcia ${ }^{2}$ and Benjamin L. Turner ${ }^{2}$ \\ ${ }^{1}$ Department of Botany and Plant Sciences, University of California, 2150 Batchelor Hall, Riverside, CA 92521, USA; \\ ${ }^{2}$ Smithsonian Tropical Research Institute, P.O. Box 0843-03092, Balboa, Ancon, Panama, Republic of Panama; \\ ${ }^{3}$ Department of Biological Sciences, Louisiana State University, 202 Life Sciences Building, Baton Rouge, LA 70803, \\ USA; ${ }^{4}$ Department of Natural Resources, Cornell University, 118 Fernow Hall, Ithaca, NY 14853, USA; and ${ }^{5}$ Mitrani \\ Department of Desert Ecology, Jacob Blaustein Institutes for Desert Research, Ben-Gurion University of the Negev, \\ 84990 Midreshet Ben-Gurion, Israel
}

\section{Summary}

1. Nutrients are a critical resource for plant growth, but the elements limiting growth in tropical forests have rarely been determined.

2. We investigated the influence of nitrogen $(\mathrm{N})$, phosphorus $(\mathrm{P})$, potassium $(\mathrm{K})$ and micronutrients on seedling biomass and nutrient allocation in a factorial nutrient fertilization experiment in lowland tropical forest at the Barro Colorado Nature Monument, Panama. We also measured 8 years of herbivory and growth for 1800 seedlings. We sought to determine the identity of limiting elements and possible nutrient interactions.

3. The five study species were Alseis blackiana, Desmopsis panamensis, Heisteria concinna, Sorocea affinis and Tetragastris panamensis. Plants grew in deeply shaded understorey with a mean canopy openness of $4.9 \%( \pm 0.7 \%$; $1 \mathrm{SE})$.

4. Tissue $\mathrm{N}$ concentration increased by $11 \%$ with $\mathrm{N}$ addition. Tissue $\mathrm{P}$ concentration increased by $16 \%$ with $\mathrm{P}$ addition. Tissue $\mathrm{K}$ increased by $4 \%$ with $\mathrm{K}$ addition. $\mathrm{K}$ addition reduced root-to-shoot biomass ratio. There was no significant effect of fertilization on specific leaf area or leaf area ratio.

5. The proportion of leaves damaged and the mean level of damage by herbivory increased with $P$ and $\mathrm{K}$ addition and showed a significant $\mathrm{P} \times \mathrm{K}$ interaction.

6. Across all species and years, relative growth rate of height increased with $\mathrm{K}$ addition and with $\mathrm{N}$ and $\mathrm{P}$ in combination. Relative growth rate of leaf count trended $8.5 \%$ higher with $\mathrm{K}$ addition $(P=0.076)$.

7. We also added micronutrients in a parallel experiment. There was no effect of micronutrient addition on any seedling parameter.

8. Synthesis. K addition affected seedlings by enhancing tissue nutrient concentration, increasing herbivory, reducing root-to-shoot biomass ratio and increasing height growth. Additional effects of $\mathrm{N}$ or $\mathrm{P}$ on tissue chemistry, herbivory and growth offer support for the multiple limiting resources hypothesis. Our results suggest that seedling growth is limited by nutrients, especially K, even under highly shaded conditions in this lowland tropical forest.

Key-words: Barro Colorado Nature Monument, fertilization, herbivory, Liebig's law of the minimum, multiple limiting resources hypothesis, nutrient limitation, Panama, plant-soil (below-ground) interactions, relative growth rate, tropical forest

\section{Introduction}

Light is considered the most limiting resource in the understorey of tropical forests (Coomes \& Grubb 2000), with often $<1 \%$ of ambient light reaching the forest floor (Björkman \&

*Correspondence author. E-mail: santiago@ucr.edu
Ludlow 1972; Chazdon \& Fetcher 1984). One model of nutrient limitation, Liebig's law of the minimum, postulates that growth is controlled by the resource in the lowest supply and only increases with added amount of that resource. Liebig's law of the minimum therefore suggests that nutrient addition might have no effect on seedling growth in highly shaded conditions. An alternative model of nutrient limitation, the 
multiple limiting resources hypothesis (Bloom, Chapin \& Mooney 1985), suggests that nutrient limitation is more complex and often regulated by several interacting resources (Elser et al. 2007; Kaspari et al. 2008). The minimum light availability under which plants respond to nutrient availability varies substantially among species (Coomes \& Grubb 2000), but some pot-grown tropical rain forest tree species respond in shade of $<1 \%$ daylight (Burslem, Grubb \& Turner 1996), indicating the possibility of nutrient limitation, even in highly shaded conditions. We investigated nutrient limitation of seedling growth of five lowland tropical forest tree species in a full-factorial nitrogen $(\mathrm{N})$, phosphorus $(\mathrm{P})$ and potassium $(\mathrm{K})$ fertilization experiment and in a parallel micronutrient addition over 8 years to determine the nature of nutrient limitation and identify limiting elements.

Several recent meta-analyses of nutrient addition experiments are consistent with multiple limitation of plant growth (Tripler et al. 2006; Elser et al. 2007; LeBauer \& Treseder 2008). Tropical forests are severely underrepresented in these meta-analyses with stand-level fertilization experiments limited to just a few locations in the lowland tropics (Mirmanto et al. 1999; Newbery et al. 2002; Campo \& Vázquez-Yanes 2004; Davidson et al. 2004; Lu et al. 2010; Wright et al. 2011). Only one of the lowland tropical forest fertilization studies addresses seedling growth in response to nutrient addition and demonstrates increased seedling growth with $\mathrm{N}$ addition in young secondary forest and with $\mathrm{P}$ addition in 60-year-old forest (Ceccon, Sanchez \& Campo 2004). This study also documents increases in foliar nutrient concentration and herbivory with fertilization (Campo \& Dirzo 2003), suggesting that enhanced herbivory with elevated nutrient supply could mask growth responses to fertilization (Andersen et al. 2010).

Because of the scarcity of fertilization experiments in oldgrowth lowland tropical forest, much of our understanding of resource limitation in tropical forest seedlings has come from root trenching experiments and pot studies. Root trenching experiments eliminate below-ground competition by plants surrounding a focal plant, thereby increasing nutrient and moisture availability, and have generally shown a positive effect on growth rate in tropical forest understorey on infertile soils and where there is seasonal drought, but not where soils are nutrient rich and drought is rare (Ostertag 1998; Coomes \& Grubb 2000; Barberis \& Tanner 2005). Root trenching experiments are thus valuable for assessing the simultaneous effects of nutrient and moisture availability on plant growth, including competitive interactions, but such experiments are not designed to determine the identity of limiting elements. In other experimental studies, tropical forest tree seedlings have been shown to increase growth in response to addition of N, P and Mg in pots (Burslem, Grubb \& Turner 1996; Lawrence 2003). Positive growth responses to combined nutrient addition have also been observed in pots (Cai et al. 2008) and in wild plants in situ (Yavitt \& Wright 2008).

Based on the total amount of nutrients circulating in litterfall, several meta-analyses suggest that $\mathrm{N}$ likely limits plant growth in tropical montane and white-sand forests, and $\mathrm{P}$ or another rock-derived element limits plant growth in most low- land tropical forests (Vitousek \& Sanford 1986; Tanner, Vitousek \& Cuevas 1998). Nutrient limitation by K has been relatively less studied in forested ecosystems in comparison with $\mathrm{N}$ and $\mathrm{P}$ despite its vital function in sustaining nutrition and primary productivity (Tripler et al. 2006). Ours is the only $\mathrm{K}$ fertilization experiment in a tropical forest (Wright et al. 2011).

Our factorial experiment assesses nutrient limitations on a relatively fertile lowland tropical soil and captures the complex interactions associated with growth responses to nutrient supply in naturally regenerating tree seedlings. The addition of $\mathrm{N}$, $\mathrm{P}$ and $\mathrm{K}$ increased soil concentrations of plant available forms of the same element (Yavitt et al. 2011). Nonetheless, we did not expect a growth response to $\mathrm{N}$ addition because $\mathrm{N}$ is widely hypothesized to be superabundant in lowland tropical forests and soil $\mathrm{N}$ availability is relatively high at our site (Yavitt et al. 2009). The amount of $\mathrm{N}$ in litterfall ranges from 156 to $195 \mathrm{~kg} \mathrm{~N} \mathrm{ha}^{-1}$ year $^{-1}$ (Haines \& Foster 1977; Yavitt, Wright \& Wieder 2004; Kaspari et al. 2008; Wright et al. 2011), which represents the high fertility range for tropical forests (Vitousek 1984). We expected a growth response to $P$ addition because $P$ is widely hypothesized to be limiting in lowland tropical forests (Vitousek 1984; Hedin et al. 2009). However, soil P availability is also relatively high at our site (Yavitt et al. 2009). The amount of $\mathrm{P}$ in litterfall ranges from 6.4 to $11 \mathrm{~kg} \mathrm{P} \mathrm{ha}^{-1}$ year $^{-1}$ (Yavitt, Wright \& Wieder 2004; Kaspari et al. 2008; Wright et al. 2011), which represents the middle to high fertility range for tropical forests (Vitousek 1984). In addition, soil $\mathrm{P}$ availability is greater at our site than at 58 of 62 Amazonian sites (Fyllas et al. 2009). Substantially less is known about the relative availability of $\mathrm{K}$ in contrasting tropical forests. Mean leaf $\mathrm{K}$ concentration at the current study site is $11.3 \mathrm{mg} \mathrm{g}^{-1}$ (Sayer \& Tanner 2010), which is slightly higher than the mean leaf $\mathrm{K}$ concentration of $6.9 \mathrm{mg} \mathrm{g}^{-1}$ for 508 tree species in 62 plots across the Amazon Basin (Fyllas et al. 2009), suggesting that the current study site is also relatively fertile in terms of $\mathrm{K}$ availability. In contrast to $\mathrm{N}$ and $\mathrm{P}$, which cycle primarily through litterfall and root turnover, $\mathrm{K}$ cycles largely in solution as throughfall and stemflow, so tropical forests retain $\mathrm{K}$ by very efficient uptake by roots. Therefore, we expected that added $\mathrm{K}$ would decrease the need for fine-root biomass and result in more growth allocation above-ground than belowground.

\section{Materials and methods}

\section{STUDY SITE AND SPECIES}

The study was conducted in mature lowland tropical forest (c. 200 year old) on the Gigante Peninsula $\left(9^{\circ} 06^{\prime} 31^{\prime \prime} \mathrm{N}\right.$, $79^{\circ} 50^{\prime} 37^{\prime \prime}$ W), within the Barro Colorado Nature Monument in Central Panama. Annual precipitation averages $2600 \mathrm{~mm},<10 \%$ of which falls during the 4-month dry season. The soils are Endogleyic Cambisols and Acric Nitisols (FAO 2006; Koehler et al. 2009). Nutrient concentrations in the top $10 \mathrm{~cm}$ of control plot soils were $84 \mathrm{mg} \mathrm{kg}^{-1}$ Mehlich III extractable plant available $\mathrm{K}, 5.3-$ $5.6 \mathrm{mg} \mathrm{kg}^{-1} 2 \mathrm{~mol} \mathrm{~L}^{-1} \mathrm{KCl}$ extractable nitrate, $6.2-15.5 \mathrm{mg} \mathrm{kg}^{-1}$ $2 \mathrm{~mol} \mathrm{~L}^{-1} \mathrm{KCl}$ extractable ammonium and $1.4 \mathrm{mg} \mathrm{kg}^{-1}$ Mehlich III 
extractable plant available P (Yavitt et al. 2009; Sayer \& Tanner 2010; Wright et al. 2011). Thus, extractable N, P and K at the study site are similar to values for soils derived from the andesite formation in the Center for Tropical Forest Science 50-ha forest dynamics plot on nearby Barro Colorado Island (Yavitt \& Wright 1996; Barthold, Stallard \& Elsenbeer 2008; Dieter, Elsenbeer \& Turner 2010).

Seedlings of five of the most common woody tree species at the site were selected for measurement: Alseis blackiana Hemsl. (Rubiaceae), Desmopsis panamensis (B.L. Rob.) Saff. (Annonaceae), Heisteria concinna Standl. (Olacaceae), Sorocea affinis Hemsl. (Moraceae) and Tetragastris panamensis (Engl.) Kunze. (Burseraceae). Species will be referred to by generic names only. All five species are relatively shade tolerant as seedlings, but span a wide range of maximum adult heights (Wright et al. 2003; Gilbert et al. 2006). Tetragastris is a canopy tree. Alseis is a medium-sized tree growing just into the canopy whose seedlings recruit from tiny, wind-dispersed seeds exclusively in canopy gaps, but unlike other pioneer tree species, are able to persist in the shaded understorey (Dalling et al. 2001). Sorocea is a shrub to small tree of the forest understorey. Desmopsis is a small tree of the forest understorey. Heisteria is a small tree that sometimes reaches the canopy (Croat 1978). Sorocea, Desmopsis and Heisteria reproduce under closed canopies of taller trees.

\section{EXPERIMENTAL DESIGN}

The eight treatments of a $2 \times 2 \times 2$ factorial NPK experiment were replicated four times across a $480 \times 800 \mathrm{~m}$ plot. The four replicates were arranged perpendicular to a $36-\mathrm{m}$ topographic gradient because soil properties (Yavitt et al. 2009) and tree distributions (S. J. Wright, unpubl. data) parallel the gradient. Within each replicate, we blocked the N, P, K and NPK treatments versus the NP, NK, PK and control treatments (see map in Yavitt et al. 2011). This balanced, incomplete block design minimizes uncontrolled error associated with spatial variation, enables evaluation of main effects and two-way interactions, but limits power to evaluate the three-way interaction (Winer, Brown \& Michels 1991). The 32 experimental plots were $40 \times 40 \mathrm{~m}$, and the minimum distance between plots was $40 \mathrm{~m}$, except for two plots separated by $20-\mathrm{m}$ and a 3 -m-deep streambed.

Stand-level fertilization was initiated in 1998, with fertilizer added by hand in four equal doses each wet season with 6-8 weeks between applications (May 15-30, July 1-15, September 1-15 and October 15-30). Fertilizers are applied at annual dosages of $125 \mathrm{~kg} \mathrm{~N}^{-1}$ year $^{-1}$ (as urea), $50 \mathrm{~kg} \mathrm{P} \mathrm{ha}^{-1}$ year $^{-1}$ (as triple super-phosphate) and $50 \mathrm{~kg} \mathrm{~K} \mathrm{ha}^{-1}$ year $^{-1}$ (as $\mathrm{KCl}$ ). Four additional plots were treated with a micronutrient fertilizer (Scott's Soluble Trace Element Mix) composed of $\mathrm{HBO}_{2}, \mathrm{CuSO}_{4}, \mathrm{FeSO}_{4}, \mathrm{MnSO}_{4}, \mathrm{ZnSO}_{4}$ and $\left(\mathrm{NH}_{4}\right)_{6} \mathrm{Mo}_{7} \mathrm{O}_{24}$ at $25 \mathrm{~kg} \mathrm{ha}^{-1}$ year $^{-1}$ plus dolomitic limestone $\mathrm{CaMg}\left(\mathrm{CO}_{3}\right)_{2}$ at $230 \mathrm{~kg} \mathrm{ha}^{-1}$ year $^{-1}$.

\section{SEEDLING MEASUREMENTS}

In 2000, after 2 years of fertilization, four plants of each species in each plot were harvested for nutrient and biomass analysis. The harvested plants were $c .10-15 \mathrm{~cm}$ tall, were located in the understorey away from gaps and were separated from one another by at least $2 \mathrm{~m}$. From each harvested individual, we separated old leaves, new leaves, stem and roots. New leaves $(<1$ year old $)$ were separated from older leaves by their colour and texture. Leaf area was determined with an area meter (3100; Li-Cor Biosciences, Lincoln, NE, USA). Samples were dried at $60{ }^{\circ} \mathrm{C}$ to constant mass. Each tissue type was ground to a fine powder and analysed for total $\mathrm{P}$ and $\mathrm{K}$ concentration using inductively coupled plasma optical emission spectrometry after nitric acid digestion. Total $\mathrm{N}$ concentration was determined with an elemental analyzer (ECS 4010; Costech Inc., Valencia, CA, USA). Specific leaf area (SLA) was calculated as leaf area per leaf mass without the petiole $\left(\mathrm{cm}^{2} \mathrm{~g}^{-1}\right)$. Leaf area ratio (LAR) was calculated as whole plant leaf area per total plant mass $\left(\mathrm{cm}^{2}\right.$ leaf $\mathrm{g}^{-1}$ plant). Root-toshoot ratio $(\mathrm{R} / \mathrm{S})$ was calculated as total below-ground mass per total above-ground mass $\left(\mathrm{g} \mathrm{g}^{-1}\right)$.

In 1998, up to ten wild seedlings of each species in the inner $20 \times 20 \mathrm{~m}$ of each study plot were marked with uniquely numbered plastic stem tags for a total of 1800 seedlings. Herbivory was assessed as leaf damage on a qualitative 10-point scale for every leaf on every plant in plots 4-18 in 1999, in plots 1-8 only in 2000 and in all 36 plots in 2001, 2002, 2003 and 2005. The same seedlings were measured for height (nearest $1 \mathrm{~mm}$ ), number of leaves and per cent canopy openness using a spherical densiometer in all plots in 1998, 1999, 2000, 2001, 2003 and 2005. Relative growth rate of height $\left(\mathrm{RGR}_{\mathrm{H}}\right.$; $\mathrm{cm} \mathrm{cm}^{-1}$ year $\left.^{-1}\right)$ was calculated for each census interval as $\left(\ln H_{1}-\right.$ $\left.\ln H_{0}\right) /\left(t_{1}-t_{0}\right)$ where $H_{0}$ and $H_{1}$ were initial and final heights $(\mathrm{cm})$ and $t_{1}-t_{0}$ was the time period (year). We used a similar equation to estimate relative growth rate of leaf count $\left(\mathrm{RGR}_{\mathrm{L}}\right)$.

\section{STATISTICAL ANALYSES}

We performed factorial anOvas to evaluate responses for tissue nutrient concentrations, allocation responses and herbivory. We also performed factorial multivariate analyses of variance (MANOva) to evaluate responses of the four tissue types simultaneously for each tissue nutrient ( $\mathrm{N}, \mathrm{P}$ and $\mathrm{K})$. We performed repeated-measures ANOVA for growth responses $\left(\mathrm{RGR}_{\mathrm{H}}\right.$ and $\left.\mathrm{RGR}_{\mathrm{L}}\right)$ with repeated measures on the five census intervals. Between-subject (or plot) effects evaluated responses over the entire experiment. Within-subject (or plot) effects evaluated variation among years and interactions among treatments and year. Greenhouse-Geisser epsilon values were used to correct for violations of the compound symmetry assumption of repeated-measures ANOVA. We performed parallel univariate, multivariate and repeated-measures ANOVAS to evaluate responses to the micronutrient addition relative to the control plots.

Our response variables pooled the five seedling species because Alseis was absent from one plot and, more importantly, our factorial incomplete block design cannot accommodate a split plot design (with every species present in every plot and a random plot effect). We calculated a single pooled response variable for each plot in four steps for tissue nutrient, allocation and growth responses. The first step evaluated distributions of individual seedling values and identified outliers and transformations to normalize the distributions. Just three outliers were excluded (two tissue $\mathrm{P}$ and one tissue $\mathrm{K}$ concentrations). Logarithmic transformations were taken for $\mathrm{R} / \mathrm{S}$ and root $\mathrm{K}$ concentrations, new leaf $\mathrm{N}$ concentrations and old and new leaf and stem P concentrations. No other transformations were necessary. The second step standardized values for individual seedlings of each species to standard normal deviates (SNDs), so that all five species were on a common scale with mean of zero and standard deviation of one. The third step averaged SNDs over all individuals of each species in each plot. The final step averaged the five (four in the one plot that lacked Alseis) species mean SNDs for each plot. Thus, the final response variables weighted the five species equally for each replicate plot.

We followed a different, two-step procedure for herbivory because individual seedlings have too few leaves to obtain meaningful estimates of herbivory. The first step calculated the proportion of leaves damaged by herbivores and the mean proportion of leaf area removed for each species and plot with censuses and individuals 
pooled. The second step averaged these values over the five (four in the one plot that lacked Alseis) species for each plot. Again, the final response variables weighted the five species equally for each replicate plot.

\section{Results}

Tissue nutrient concentration responded strongly to nutrient addition. In the MANOvA, across all four tissue types, $\mathrm{N}$ addition increased tissue $\mathrm{N}$ concentration by $11 \%(P<0.001)$ and $\mathrm{P}$ addition increased tissue $\mathrm{P}$ concentration by $16 \%(P<0.001$; Table 1). There were also significant increases in tissue $\mathrm{P}$ concentration with $\mathrm{P}$ addition and in tissue $\mathrm{N}$ concentration with $\mathrm{N}$ addition for each tissue type (Table 1). The more modest increase in tissue $\mathrm{K}$ concentration with $\mathrm{K}$ addition was only significant for roots $(P<0.05)$.

Herbivory was assessed for a total of 31040 leaves. ANOvA results were similar for the two related response variables (Fig. 1, Table 2). P and $\mathrm{K}$ addition each caused increases in the proportion of leaves damaged and the mean level of leaf damage. There were also significant $\mathrm{P} \times \mathrm{K}$ interactions, with greater herbivory when $\mathrm{P}$ and $\mathrm{K}$ were added in combination.

There were no significant effects of nutrient addition for SLA (Fig. 2a, Table 3). LAR tended to be larger when $\mathrm{N}$ and

Table 1. Multivariate and univariate $F$-statistics for the effects of nutrient addition on $\mathrm{N}, \mathrm{P}$ and $\mathrm{K}$ concentrations in young leaves, old leaves, stems and roots

\begin{tabular}{|c|c|c|c|c|c|}
\hline \multirow[b]{2}{*}{ Effect } & \multirow[b]{2}{*}{$\begin{array}{l}\text { Multivariate } \\
F \text {-statistics }\end{array}$} & \multicolumn{4}{|c|}{ Univariate $F$-statistics } \\
\hline & & $\begin{array}{l}\text { Young } \\
\text { leaves }\end{array}$ & $\begin{array}{l}\text { Old } \\
\text { leaves }\end{array}$ & Stem & Root \\
\hline \multicolumn{6}{|c|}{$\mathrm{N}$ concentration } \\
\hline $\mathrm{N}$ & $16.9 * * *$ & $30.5^{* * *}$ & $10.2 * * *$ & $24.1 * * *$ & $56.3^{* * *}$ \\
\hline $\mathrm{P}$ & 1.50 & 1.09 & 0.822 & 3.24 & 2.47 \\
\hline $\mathrm{K}$ & 1.56 & 0.536 & 2.34 & 1.48 & $6.67^{*}$ \\
\hline $\mathrm{N} \times \mathrm{P}$ & 0.109 & $6.43^{*}$ & 1.27 & 0.385 & 0.0331 \\
\hline $\mathrm{N} \times \mathrm{K}$ & 1.13 & 2.69 & 0.187 & 0.332 & 4.52 \\
\hline $\mathrm{P} \times \mathrm{K}$ & $\begin{array}{l}3.20 \\
(P=0.053)\end{array}$ & $5.45^{*}$ & 2.27 & 0.397 & $12.8^{* *}$ \\
\hline \multicolumn{6}{|c|}{$\mathrm{P}$ concentration } \\
\hline $\mathrm{N}$ & 1.44 & 0.000 & 1.36 & 3.47 & 1.80 \\
\hline $\mathrm{P}$ & $14.5^{* * *}$ & $8.94 * *$ & $12.2^{* *}$ & $35.8 * * *$ & $46.1 * * *$ \\
\hline K & 1.07 & 0.575 & 0.0128 & 0.00389 & 3.36 \\
\hline $\mathrm{N} \times \mathrm{P}$ & 0.979 & 0.469 & 0.329 & 0.975 & 0.925 \\
\hline $\mathrm{N} \times \mathrm{K}$ & 1.85 & 1.83 & 0.153 & 2.88 & $4.99 *$ \\
\hline $\mathrm{P} \times \mathrm{K}$ & $3.13^{*}$ & 0.0461 & 0.000245 & $4.61^{*}$ & 1.09 \\
\hline \multicolumn{6}{|c|}{$\mathrm{K}$ concentration } \\
\hline $\mathrm{N}$ & 2.10 & 0.350 & 1.01 & 2.32 & $9.78 * *$ \\
\hline $\mathrm{P}$ & 2.11 & 3.77 & 0.0432 & 1.28 & 0.410 \\
\hline K & $\begin{array}{l}2.99 \\
(P=0.053)\end{array}$ & 1.93 & 0.133 & 0.411 & $4.96^{*}$ \\
\hline $\mathrm{N} \times \mathrm{P}$ & 0.762 & 0.0393 & 0.373 & 0.496 & 1.01 \\
\hline $\mathrm{N} \times \mathrm{K}$ & 0.467 & 0.891 & 0.0820 & 0.0559 & 0.00613 \\
\hline $\mathrm{P} \times \mathrm{K}$ & 0.820 & 0.247 & 0.203 & 0.442 & 0.583 \\
\hline
\end{tabular}

Degrees of freedom are 1,18 for univariate and 4,15 for multivariate $F$-statistics for $\mathrm{P}$ and $\mathrm{K}$. The laboratory lost samples from three plots before $\mathrm{N}$ determinations and degrees of freedom are 1,15 and 4,12 for univariate and multivariate $F$-statistics, respectively. Significance: $* P \leq 0.05 ; * * P \leq 0.01 ; * * * P \leq 0.001$.
$\mathrm{P}$ were added in combination $(P=0.066$; Fig. $2 \mathrm{~b}$, Table 3$)$. However, $\mathrm{K}$ addition caused a significant reduction in $\mathrm{R} / \mathrm{S}$ (Fig. 2c, Table 3).

Mean species-specific $\mathrm{RGR}_{\mathrm{H}} \quad(\bar{x} \pm 1 \mathrm{SE})$ varied from $0.045 \pm 0.004 \mathrm{~cm} \mathrm{~cm}^{-1}$ year $^{-1}$ in Alseis to $0.092 \pm$ $0.006 \mathrm{~cm} \mathrm{~cm}^{-1}$ year $^{-1}$ in Desmopsis. There was a significant increase in seedling $\mathrm{RGR}_{\mathrm{H}}$ of $24 \%$ with $\mathrm{K}$ addition (Fig. 3a, Table 4). There was also a significant $\mathrm{N} \times \mathrm{P}$ interaction with greater seedling height growth when $\mathrm{N}$ and $\mathrm{P}$ were added in combination (Fig. 3a, Table 4). RGR $_{\mathrm{L}}$ trended $8.5 \%$ higher with $\mathrm{K}$ addition (Fig. 3b; $P=0.076$ ), and no other effects on RGR $_{\mathrm{L}}$ were observed (Table 4).

Mean per cent canopy openness above experimental seedlings was $4.9 \pm 0.7 \%$ (range $<1-24.5 \%$ ) and was not strongly related to $\mathrm{RGR}_{\mathrm{H}}$ or $\mathrm{RGR}_{\mathrm{L}}\left(R^{2}<0.01\right)$. Evaluation of methods to estimate understorey light conditions in tropical forest indicates that canopy openness as recorded by a spherical densiometer is only weakly correlated with direct measures of light availability (Engelbrecht \& Herz 2001). Our spherical densiometer measurements were likely too coarse to sense the level of variation in light availability that affects seedling growth in this forest.

There were no significant effects of micronutrients on any growth or biomass parameters.

\section{Discussion}

Our long-term, stand-level fertilization experiment establishes that added $\mathrm{N}, \mathrm{P}$ and $\mathrm{K}$ increase seedling tissue concentrations of N, P and $\mathrm{K}$ (Table 1), respectively. Added $\mathrm{P}$ and $\mathrm{K}$ but not added $\mathrm{N}$ increased herbivory on leaves (Fig. 1, Table 2). This suggests that herbivores might be more limited by tissue $\mathrm{P}$ and $\mathrm{K}$ concentrations than by tissue $\mathrm{N}$ concentrations in this lowland tropical forest growing on a relatively fertile soil. Fertilization with $\mathrm{K}$ also reduced allocation to roots (Fig. 2c, Table 3) and increased above-ground growth (Table 4). This suggests a mechanistic link between allocation to roots for acquiring $\mathrm{K}$ and above-ground growth. Fertilization with $\mathrm{N}$ and $\mathrm{P}$ together also increased height growth (Table 4), indicating that the multiple limiting resources model provides an appropriate context for feedbacks between resource availability and plant growth and allocation.

We did not expect a growth response to $\mathrm{N}$ addition because $\mathrm{N}$ availability is relatively high at our study site. $\mathrm{N}$ addition increased tissue $\mathrm{N}$ concentration consistent with other $\mathrm{N}$ fertilization studies in tropical forest (Cordell et al. 2001; Campo \& Dirzo 2003; Andersen et al. 2010). Enhanced seedling height growth with combined $\mathrm{N}$ and $\mathrm{P}$ addition provides evidence for co-limitation by $\mathrm{N}$ and $\mathrm{P}$ (Fig. 3, Table 4). $\mathrm{N}$ is not commonly stored as inorganic $\mathrm{N}$ in leaves, but rather in forms such as amino acids or proteins, thus incurring a metabolic cost for storage (Chapin, Schulze \& Mooney 1990). Therefore, in comparison with elements such as $\mathrm{P}$ or $\mathrm{K}$ that can be stored inorganically with little cost, $\mathrm{N}$ may require constant turnover in plants, causing a large demand that could promote intermittent $\mathrm{N}$ limitation of plant growth (Ostertag 2010). N limitation of plant processes has been observed in a variety of tropical 

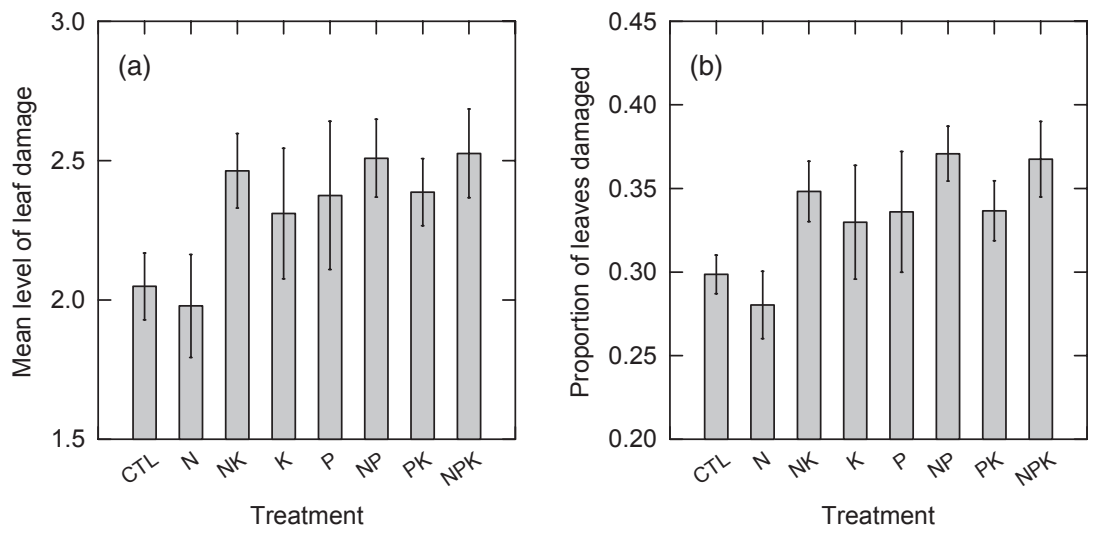

Fig. 1. Responses of tree seedling herbivory to N, P and K addition in lowland tropical forest at the Barro Colorado Nature Monument, Panama: (a) Mean level of leaf damage; (b) proportion of leaves damaged. The six treatments involving $\mathrm{P}$ or $\mathrm{K}$ are to the right to illustrate the significant effects of $\mathrm{P}$ and $\mathrm{K}$ addition (see Table 2 for statistical results). CTL represents the control treatment. Bars represent mean values $( \pm 1 \mathrm{SE})$ for four plots.

Table 2. Results of analysis of variance for mean level of leaf damage and proportion of leaves damaged for seedlings of five tropical tree species in response to 8 years of fertilization with $\mathrm{N}, \mathrm{P}$ and $\mathrm{K}$. Bold type indicates statistical significance of $P \leq 0.05$

\begin{tabular}{|c|c|c|c|c|c|}
\hline \multirow[b]{2}{*}{ Source } & \multirow[b]{2}{*}{ d.f. } & \multicolumn{2}{|c|}{$\begin{array}{l}\text { Mean level } \\
\text { of damage }\end{array}$} & \multicolumn{2}{|c|}{$\begin{array}{l}\text { Proportion of } \\
\text { leaves damaged }\end{array}$} \\
\hline & & $F$ & $P$ & $F$ & $P$ \\
\hline \multicolumn{6}{|l|}{ Between blocks } \\
\hline Rep & 3 & 2.40 & 0.101 & 2.90 & 0.063 \\
\hline Block (Rep) & 4 & 6.94 & 0.001 & 6.30 & 0.002 \\
\hline \multicolumn{6}{|l|}{ Within blocks } \\
\hline $\mathrm{N}$ & 1 & 1.45 & 0.245 & 2.951 & 0.103 \\
\hline$P$ & 1 & 12.28 & 0.003 & 16.16 & 0.001 \\
\hline $\mathrm{K}$ & 1 & 7.10 & 0.016 & 6.35 & 0.021 \\
\hline $\mathrm{N} \times \mathrm{P}$ & 1 & 0.39 & 0.541 & 2.93 & 0.104 \\
\hline $\mathrm{N} \times \mathrm{K}$ & 1 & 0.70 & 0.415 & 0.74 & 0.403 \\
\hline $\mathrm{P} \times \mathrm{K}$ & 1 & 6.43 & 0.021 & 7.05 & 0.016 \\
\hline Error & 18 & & & & \\
\hline
\end{tabular}

soils (Cuevas \& Medina 1988; Vitousek et al. 1993; Mirmanto et al. 1999; Kaspari et al. 2008; Graefe, Hertel \& Leuschner 2010), and our results are consistent with the possibility that even in N-rich tropical forests, plants may always be able to use more N (Kaspari et al. 2008). It is important to note that our $\mathrm{N}$ treatment reduced soil $\mathrm{pH}$ by $0.5 \mathrm{pH}$ units (Yavitt et al. 2011). Therefore, our $\mathrm{N}$ treatments might induce limitation by some other nutrient and should thus be interpreted with caution.

We expected significant growth responses to $\mathrm{P}$ addition because of the limited mobility of $\mathrm{P}$ in soils (Nye \& Tinker 1977) and the highly weathered, low $P$ soils in many lowland tropical forests (Vitousek \& Sanford 1986; Cavelier 1992; Santiago, Schuur \& Silvera 2005). In addition, studies conducted in pots (Burslem, Grubb \& Turner 1995; Gunatilleke et al. 1997) and in the field (Herbert \& Fownes 1995) have demonstrated responses of tropical forest plants to P. However, we found that $\mathrm{RGR}_{\mathrm{H}}$ only responded to $\mathrm{P}$ in combination with $\mathrm{N}$, whereas $\mathrm{RGR}_{\mathrm{L}}$ showed no response to P (Fig. 3b, Table 4).
These results are consistent with the P-rich Miocene basalt bedrock at our site and the $6.4-11 \mathrm{~kg} \mathrm{ha}^{-1}$ year $^{-1}$ of $\mathrm{P}$ input in litter at the study site (Wright et al. 2011), which is moderate to relatively high among tropical forests (Vitousek 1984). Not all lowland tropical forests are characterized by low $\mathrm{P}$ availability (Dieter, Elsenbeer \& Turner 2010). However, the lack of a strong $\mathrm{P}$ effect on growth is also consistent with the possibility that increased herbivory with $\mathrm{P}$ addition obscured any growth effect. For example, Andersen et al. (2010) report no growth effect, but the $47 \%$ increase in herbivory with $\mathrm{N}$ addition might have obscured possible growth responses.

The allocation and growth responses to $\mathrm{K}$ addition were striking (Figs $2 \mathrm{c}$ and $3 \mathrm{a}$ ). $\mathrm{K}^{+}$is the most abundant ion in plant cells and is critical for a host of biochemical pathways including osmoregulation, photosynthesis, cell extension, oxidative phosphorylation and protein activation (Evans \& Sorger 1966; Marschner 1995; Santiago \& Wright 2007). Despite these vital functions, the physiological mechanisms of $\mathrm{K}$ limitation of forest productivity have been investigated substantially less often than $\mathrm{N}$ and $\mathrm{P}$ (Tripler et al. 2006). Our results suggest that $\mathrm{K}$ availability can have a large effect on forest seedling growth. If $\mathrm{K}$ limitation is widespread, an understanding of $\mathrm{K}$ cycles will be critically needed to predict forest responses to environmental change. $\mathrm{K}$ is highly mobile in soils and leaches away quickly, so its supply should become rapidly dominated by atmospheric deposition during ecosystem development (Chadwick et al. 1999). Atmospheric $\mathrm{K}$ deposition includes two main sources: (i) marine salts and (ii) wind-blown silt and clay (aeolian dust). Because our study site is 31.6 and $23.0 \mathrm{~km}$ to the Pacific Ocean and Caribbean Sea, respectively, it is likely that marine salts dominate local $\mathrm{K}$ deposition (Boy \& Wilcke 2008) and that local $\mathrm{K}$ deposition is larger than in many continental tropical forests. $\mathrm{K}$ is likely to be limiting in continental tropical forests on ancient geological formations. Studies that integrate ecosystem-scale nutrient budgets with measures of plant productivity will improve our understanding of $\mathrm{K}$ limitation. 

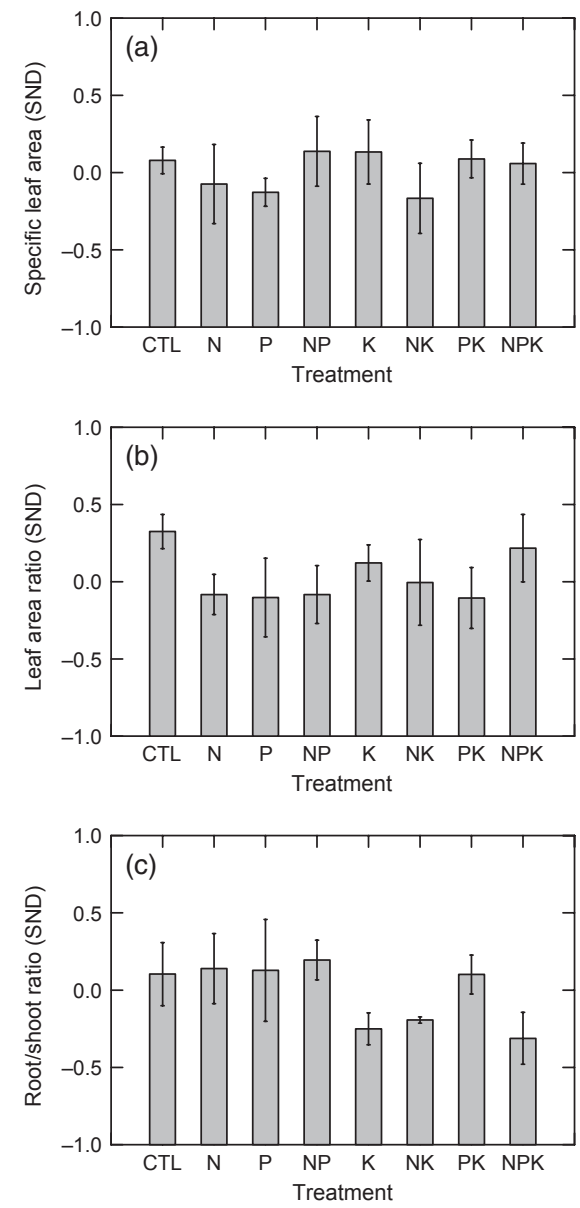

Fig. 2. Responses of seedling biomass allocation to the eight treatments in the factorial N-P-K design. Panel a shows specific leaf area (no significant effects). Panel b shows leaf area ratio (no significant effects). Panel c shows root-to-shoot biomass ratio with four treatments involving $\mathrm{K}$ to the right to illustrate the significant effect of $\mathrm{K}$ addition $\left(F_{1,18}=6.55, P=0.020\right)$. CTL represents the control treatment. Bars represent mean values $( \pm 1 \mathrm{SE})$ for four plots. See Table 3 for complete statistical results.

The growth responses to added nutrients observed in the shaded understorey are consistent with at least two mechanisms. First, increased nutrient supply enables increased uptake of another limiting resource such as light (Fahey, Battles \& Wilson 1998). Such 'resource substitution' would be consistent with the expectations of the model of multiple limiting resources (Bloom, Chapin \& Mooney 1985). Consistent with this idea, increases in foliar nutrient concentration in seedlings of one of the study species, A. blackiana, are associated with enhanced maximum photosynthetic rates and alterations of light harvesting and stomatal behaviour in a manner that increases carbon gain during short-duration, high-intensity sunflecks (S. C. Pasquini \& L. S. Santiago, unpubl. data). Therefore, even in the light-limited understorey, added nutrients may be allocated to enhance plant carbon gain. The second possible mechanism relating nutrient addition and aboveground growth responses concerns allocation to roots. Plants are known to acclimate to increases in nutrient availability by
Table 3. Results of analysis of variance for specific leaf area (SLA), leaf area ratio (LAR) and root-to-shoot biomass ratio $(\mathrm{R} / \mathrm{S})$ for seedlings of five tropical tree species in response to fertilization with $\mathrm{N}, \mathrm{P}$ and $\mathrm{K}$. Bold type indicates statistical significance of $P \leq 0.05$

\begin{tabular}{|c|c|c|c|c|c|c|c|}
\hline \multirow[b]{2}{*}{ Source } & \multirow[b]{2}{*}{ d.f. } & \multicolumn{2}{|l|}{ SLA } & \multicolumn{2}{|c|}{ LAR } & \multicolumn{2}{|l|}{$\mathrm{R} / \mathrm{S}$} \\
\hline & & $F$ & $P$ & $F$ & $P$ & $F$ & $P$ \\
\hline \multicolumn{8}{|l|}{ Between blocks } \\
\hline Rep & 3 & 5.72 & 0.006 & 0.84 & 0.488 & 0.50 & 0.689 \\
\hline Block (Rep) & 4 & 1.42 & 0.267 & 1.30 & 0.308 & 0.44 & 0.778 \\
\hline \multicolumn{8}{|l|}{ Within blocks } \\
\hline $\mathrm{N}$ & 1 & 0.33 & 0.572 & 0.18 & 0.674 & 0.28 & 0.601 \\
\hline $\mathrm{P}$ & 1 & 0.61 & 0.447 & 0.94 & 0.346 & 0.43 & 0.520 \\
\hline K & 1 & 0.03 & 0.871 & 0.15 & 0.704 & 6.55 & 0.020 \\
\hline $\mathrm{N} \times \mathrm{P}$ & 1 & 2.84 & 0.109 & 3.85 & 0.066 & 0.85 & 0.369 \\
\hline $\mathrm{N} \times \mathrm{K}$ & 1 & 3.35 & 0.084 & 1.72 & 0.207 & 0.93 & 0.349 \\
\hline $\mathrm{P} \times \mathrm{K}$ & 1 & 0.62 & 0.441 & 0.89 & 0.358 & 0.10 & 0.750 \\
\hline Error & 18 & & & & & & \\
\hline
\end{tabular}
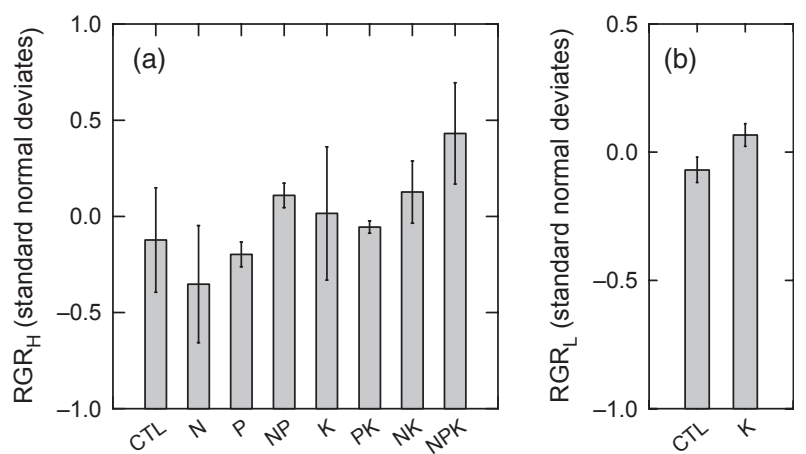

Fig. 3. Effects of $\mathrm{N}, \mathrm{P}$ and $\mathrm{K}$ addition on tree seedling growth in lowland Panamanian forest at the Barro Colorado Nature Monument. Panel a shows relative growth rate of height $\left(\mathrm{RGR}_{\mathrm{H}}\right)$ with the four treatments involving $\mathrm{K}$ to the right to illustrate the significant effect of $\mathrm{K}$ addition $\left(F_{1,18}=6.87, P=0.017\right)$. Panel $\mathrm{b}$ shows the trend of an effect of $\mathrm{K}$ addition on relative growth rate of leaf count $\left(\mathrm{RGR}_{\mathrm{L}}\right)$ $\left(F_{1,18}=3.53, P=0.076\right)$. CTL represents the control treatment. Bars represent mean RGR values ( $\pm 1 \mathrm{SE}$ ) for four and sixteen plots in panels A and B, respectively.

decreasing allocation to roots relative to leaves (Garnier 1991; Marschner 1995). These responses are thought to maximize growth rate by balancing acquisition of above-ground versus below-ground resources through allocation to obtain resources that most limit growth (Bloom, Chapin \& Mooney 1985). Our observed reduction in $\mathrm{R} / \mathrm{S}$ with $\mathrm{K}$ addition is consistent with this hypothesis. Furthermore, K addition decreased stand-level fine-root biomass by $17 \%$ in these plots during the first 2 years of fertilization (Yavitt et al. 2011), and this effect was present in these plots after 11 years of fertilization (Wright et al. 2011). Fertilization with $\mathrm{K}$ is causing decreased allocation to roots that enables increased growth in height and leaf number.

Our results indicate that multiple nutrients interact to limit tree seedling growth in this tropical forest growing on relatively fertile soil. Seedlings responded to nutrient supply in the shade, indicating that increased nutrient supply can alter allocation patterns to increase growth even when light is limiting. This is the first stand-level fertilization experiment to document the 
Table 4. Results of repeated-measures analysis of variance for relative growth rate of seedling height $\left(\mathrm{RGR}_{\mathrm{H}}\right)$ and number of leaves $\left(R_{G} R_{L}\right)$ in response to 8 years of experimental fertilization with $\mathrm{N}, \mathrm{P}$ and $\mathrm{K}$ for five plant species. Bold indicates $P \leq 0.05$. GreenhouseGeisser Epsilon: $0.809 \mathrm{RGR}_{\mathrm{L}}, 0.802 \mathrm{RGR}_{\mathrm{H}}$

\begin{tabular}{|c|c|c|c|c|c|}
\hline \multirow[b]{2}{*}{ Source } & \multirow[b]{2}{*}{ d.f. } & \multicolumn{2}{|c|}{$\mathrm{RGR}_{\mathrm{H}}$} & \multicolumn{2}{|c|}{$\mathrm{RGR}_{\mathrm{L}}$} \\
\hline & & $F$ & $P$ & $F$ & $P$ \\
\hline \multicolumn{6}{|l|}{ Between plots } \\
\hline \multicolumn{6}{|l|}{ Between blocks } \\
\hline Rep & 3 & 4.67 & 0.014 & 0.75 & 0.534 \\
\hline Block (Rep) & 4 & 1.65 & 0.205 & 0.16 & 0.957 \\
\hline \multicolumn{6}{|l|}{ Within blocks } \\
\hline $\mathrm{N}$ & 1 & 2.68 & 0.119 & 0.55 & 0.467 \\
\hline $\mathrm{P}$ & 1 & 2.27 & 0.150 & 0.01 & 0.918 \\
\hline $\mathrm{K}$ & 1 & 6.87 & 0.017 & 3.53 & 0.076 \\
\hline $\mathrm{N} \times \mathrm{P}$ & 1 & 4.89 & 0.040 & 0.17 & 0.689 \\
\hline $\mathrm{N} \times \mathrm{K}$ & 1 & 1.59 & 0.223 & 0.01 & 0.924 \\
\hline $\mathrm{P} \times \mathrm{K}$ & 1 & 0.14 & 0.715 & 1.93 & 0.182 \\
\hline Error & 18 & & & & \\
\hline \multicolumn{6}{|l|}{ Within plots } \\
\hline \multicolumn{6}{|l|}{ Between blocks } \\
\hline Year $\times$ Rep & 12 & 1.58 & 0.119 & 0.79 & 0.664 \\
\hline Year × Block (Rep) & 16 & 0.65 & 0.833 & 1.00 & 0.468 \\
\hline \multicolumn{6}{|l|}{ Within blocks } \\
\hline Year & 4 & 0.01 & 1.000 & 0.00 & 1.000 \\
\hline Year $\times N$ & 4 & 0.61 & 0.657 & 0.98 & 0.425 \\
\hline Year $\times \mathrm{P}$ & 4 & 1.39 & 0.246 & 0.79 & 0.537 \\
\hline Year $\times \mathrm{K}$ & 4 & 0.82 & 0.520 & 0.48 & 0.753 \\
\hline Year $\times \mathrm{N} \times \mathrm{P}$ & 4 & 0.99 & 0.422 & 2.09 & 0.090 \\
\hline Year $\times \mathrm{N} \times \mathrm{K}$ & 4 & 1.13 & 0.350 & 0.30 & 0.877 \\
\hline Year $\times \mathrm{P} \times \mathrm{K}$ & 4 & 1.67 & 0.167 & 0.22 & 0.927 \\
\hline Error & 72 & & & & \\
\hline
\end{tabular}

nature of multiple-nutrient limitation in tropical forest tree seedlings. These results demonstrate the potential for complex interactions among multiple nutrients.

\section{Acknowledgements}

We gratefully acknowledge Omar Hernández and Rufino González for their diligent efforts in the field, Alex Barron, Walt Carson, Jennifer Powers, Jim Sickman and Klaus Winter for insightful discussions, and the Smithsonian Tropical Research Institute and the University of California, Riverside, for logistical support. This is paper number 750 of the Mitrani Department of Desert Ecology. Partial support for this study was provided by a grant from the Andrew W. Mellon Foundation to Wright, a Smithsonian Scholarly Studies grant to Wright, Harms and Yavitt, and a University of California Regent's Faculty Fellowship to Santiago.

\section{References}

Andersen, K.M., Corre, M.D., Turner, B.L. \& Dalling, J.W. (2010) Plant-soil associations in a lower montane tropical forest: physiological acclimation and herbivore-mediated responses to nitrogen addition. Functional Ecology, 24, 1171-1180.

Barberis, I.M. \& Tanner, E.V.J. (2005) Gaps and root trenching increase tree seedling growth in Panamanian semi-evergreen forest. Ecology, 86, 667-674.

Barthold, F.K., Stallard, R.F. \& Elsenbeer, H. (2008) Soil nutrient-landscape relationships in a lowland tropical rainforest in Panama. Forest Ecology and Management, 255, 1135-1148.

Björkman, O. \& Ludlow, M. (1972) Characterization of the light climate on the floor of a Queensland rainforest. Carnegie Institution of Washington Yearbook, 71, 85-91.
Bloom, A.J., Chapin III, F.S. \& Mooney, H.A. (1985) Resource limitation in plants-an economic analogy. Annual Review of Ecology and Systematics, 16, 363-392.

Boy, J. \& Wilcke, W. (2008) Tropical Andean forest derives calcium and magnesium from Saharan dust. Global Biogeochemical Cycles, 22, GB1027.

Burslem, D.F.R.P., Grubb, P.J. \& Turner, I.M. (1995) Responses to nutrient addition among shade-tolerant tree seedlings of lowland tropical rain forest in Singapore. Journal of Ecology, 83, 113-122.

Burslem, D.F.R.P., Grubb, P.J. \& Turner, I.M. (1996) Responses to simulated drought and elevated nutrient supply among shade-tolerant tree seedlings of lowland tropical forest in Singapore. Biotropica, 28, 636-648.

Cai, Z.Q., Poorter, L., Han, Q. \& Bongers, F. (2008) Effects of light and nutrients on seedlings of tropical Bauhinia lianas and trees. Tree Physiology, 28, $1277-1285$.

Campo, J. \& Dirzo, R. (2003) Leaf quality and herbivory responses to soil nutrient addition in secondary tropical dry forests of Yucatan, Mexico. Journal of Tropical Ecology, 19, 525-530.

Campo, J. \& Vázquez-Yanes, C. (2004) Effects of nutrient limitation on aboveground carbon dynamics during tropical dry forest regeneration in Yucatán, Mexico. Ecosystems, 7, 311-319.

Cavelier, J. (1992) Fine-root biomass and soil properties in a semideciduous and a lower montane rain forest in Panama. Plant and Soil, 142, 187-201.

Ceccon, E., Sanchez, S. \& Campo, J. (2004) Tree seedling dynamics in two abandoned tropical dry forests of differing successional status in Yucatan, Mexico: a field experiment with $\mathrm{N}$ and $\mathrm{P}$ fertilization. Plant Ecology, 170, 277-285.

Chadwick, O.A., Derry, L.A., Vitousek, P.M., Huebert, B.J. \& Hedin, L.O. (1999) Changing sources of nutrients during four million years of ecosystem development. Nature, 397, 491-497.

Chapin, F.S., Schulze, E.D. \& Mooney, H.A. (1990) The ecology and economics of storage in plants. Annual Review of Ecology and Systematics, 21, 423-447.

Chazdon, R.L. \& Fetcher, N. (1984) Light environments of tropical forests. Physiological Ecology of Plants of the Wet Tropics (eds E. Medina, H.A. Mooney \& C. Vázquez-Yanes), pp. 553-564. Dr. W. Junk Publishers, The Hague.

Coomes, D.A. \& Grubb, P.J. (2000) Impacts of root competition in forests and woodlands: a theoretical framework and review of experiments. Ecological Monographs, 70, 171-207.

Cordell, S., Goldstein, G., Meinzer, F.C. \& Vitousek, P.M. (2001) Regulation of leaf life-span and nutrient-use efficiency of Metrosideros polymorpha trees at two extremes of a long chronosequence in Hawaii. Oecologia, 127, 198206.

Croat, T.B. (1978) Flora of Barro Colorado Island. Stanford University Press, Stanford, California.

Cuevas, E. \& Medina, E. (1988) Nutrient dynamics within Amazonian forests. II fine root growth, nutrient availability and leaf litter decomposition. Oecologia, 76, 222-235.

Dalling, J.W., Winter, K., Nason, J.D., Hubbell, S.P., Murawski, D.A. \& Hamrick, J.L. (2001) The unusual life history of Alseis blackiana: A shadepersistent pioneer tree? Ecology, 82, 933-945.

Davidson, E.A., de Carvalho, C.J.R., Vieira, I.C.G., Figueiredo, R.D., Moutinho, P., Ishida, F.Y., dos Santos, M.T.P., Guerrero, J.B., Kalif, K. \& Saba, R.T. (2004) Nitrogen and phosphorus limitation of biomass growth in a tropical secondary forest. Ecological Applications, 14, S150-S163.

Dieter, D., Elsenbeer, H. \& Turner, B.L. (2010) Phosphorus fractionation in lowland tropical rainforest soils in central Panama. Catena, 82, 118-125.

Elser, J.J., Bracken, M.E.S., Cleland, E.E., Gruner, D.S., Harpole, W.S., Hillebrand, H., Ngai, J.T., Seabloom, E.W., Shurin, J.B. \& Smith, J.E. (2007) Global analysis of nitrogen and phosphorus limitation of primary producers in freshwater, marine and terrestrial ecosystems. Ecology Letters, 10, 11351142.

Engelbrecht, B.M.J. \& Herz, H.M. (2001) Evaluation of different methods to estimate understorey light conditions in tropical forests. Journal of Tropical Ecology, 17, 207-224.

Evans, H.J. \& Sorger, G.J. (1966) Role of mineral elements with emphasis on the univalent cations. Annual Review of Plant Physiology, 17, 47-76.

Fahey, T.J., Battles, J.J. \& Wilson, G.F. (1998) Responses of early successional northern hardwood forests to changes in nutrient availability. Ecological Monographs, 68, 183-212.

FAO (2006) World reference base for soil resources. World soil resource reports 103. FAO, Rome.

Fyllas, N.M., Patiño, S., Baker, T.R., Nardoto, G.B., Martinelli, L.A., Quesada, C.A. et al. (2009) Basin-wide variations in foliar properties of Amazonian forest: phylogeny, soils and climate. Biogeosciences, 6, 2677-2708. 
Garnier, E. (1991) Resource capture, biomass allocation and growth in herbaceous plants. Trends in Ecology \& Evolution, 6, 126-131.

Gilbert, B., Wright, S.J., Muller-Landau, H.C., Kitajima, K. \& Hernández, A. (2006) Life history trade-offs in tropical trees and lianas. Ecology, 87, 12811288.

Graefe, S., Hertel, D. \& Leuschner, C. (2010) N, P and K limitation of fine root growth along an elevation transect in tropical mountain forests. Acta Oecologica, 36, 537-542.

Gunatilleke, C.V.S., Gunatilleke, I.A.U.N., Perera, G.A.D., Burslem, D.F.R.P., Ashton, P.M.S. \& Ashton, P.S. (1997) Responses to nutrient addition among seedlings of eight closely related species of Shorea in Sri Lanka. Journal of Ecology, 85, 301-311.

Haines, B. \& Foster, R.B. (1977) Energy flow through litter in a Panamanian forest. Journal of Ecology, 65, 147-155.

Hedin, L.O., Brookshire, E.N.J., Menge, D.N.L. \& Barron, A. (2009) The nitrogen paradox in tropical forest ecosystems. Annual Review of Ecology, Evolution, and Systematics, 40, 613-635.

Herbert, D.A. \& Fownes, J.H. (1995) Phosphorus limitation of forest leaf area and net primary production on a highly weathered soil. Biogeochemistry, 29, $223-235$.

Kaspari, M., Garcia, M.N., Harms, K.E., Santana, M., Wright, S.J. \& Yavitt, J.B. (2008) Multiple nutrients limit litterfall and decomposition in a tropical forest. Ecology Letters, 11, 35-43.

Koehler, B., Corre, M.D., Veldkamp, E., Wullaert, H. \& Wright, S.J. (2009) Immediate and long-term nitrogen oxide emissions from tropical forest soils exposed to elevated nitrogen input. Global Change Biology, 15, 2049-2066.

Lawrence, D. (2003) The response of tropical tree seedlings to nutrient supply: meta-analysis for understanding a changing tropical landscape. Journal of Tropical Ecology, 19, 239-250.

LeBauer, D.S. \& Treseder, K.K. (2008) Nitrogen limitation of net primary productivity in terrestrial ecosystems is globally distributed. Ecology, 89, 371379.

Lu, X., Mo, J., Gilliam, F.S., Zhou, G. \& Fang, Y. (2010) Effects of experimental nitrogen additions on plant diversity in an old-growth tropical forest. Global Change Biology, 16, 2688-2700.

Marschner, H. (1995) Mineral Nutrition in Higher Plants. Academic Press, London.

Mirmanto, E., Proctor, J., Green, J., Nagy, L. \& Suriantata (1999) Effects of nitrogen and phosphorus fertilization in a lowland evergreen rainforest Philosophical Transactions of the Royal Society of London Series B-Biological Sciences, 354, 1825-1829.

Newbery, D.M., Chuyong, G.B., Green, J.J., Songwe, N.C., Tchuenteu, F. \& Zimmermann, L. (2002) Does low phosphorus supply limit seedling establishment and tree growth in groves of ectomycorrhizal trees in a central African rainforest? New Phytologist, 156, 297-311.

Nye, P.H. \& Tinker, P.B. (1977) Solute Movement in the Soil-Root System. University of California Press, Berkeley, California.

Ostertag, R. (1998) Belowground effects of canopy gaps in a tropical wet forest. Ecology, 79, 1294-1304.

Ostertag, R. (2010) Foliar nitrogen and phosphorus accumulation responses after fertilization: an example from nutrient-limited Hawaiian forests. Plant and Soil, 334, 85-98.
Santiago, L.S., Schuur, E.A.G. \& Silvera, K. (2005) Nutrient cycling and plantsoil feedbacks along a precipitation gradient in lowland Panama. Journal of Tropical Ecology, 21, 461-470.

Santiago, L.S. \& Wright, S.J. (2007) Leaf functional traits of tropical forest plants in relation to growth form. Functional Ecology, 21, 19-27.

Sayer, E.J. \& Tanner, E.V.J. (2010) Experimental investigation of the importance of litterfall in lowland semi-evergreen tropical forest nutrient cycling. Journal of Ecology, 98, 1052-1062.

Tanner, E.V.J., Vitousek, P.M. \& Cuevas, E. (1998) Experimental investigation of nutrient limitation of forest growth on wet tropical mountains. Ecology, 79, 10-22.

Tripler, C.E., Kaushal, S.S., Likens, G.E. \& Walter, M.T. (2006) Patterns in potassium dynamics in forest ecosystems. Ecology Letters, 9, 451-466.

Vitousek, P.M. (1984) Litterfall, nutrient cycling, and nutrient limitation in tropical forests. Ecology, 65, 285-298.

Vitousek, P.M. \& Sanford, R.L. (1986) Nutrient cycling in moist tropical forest. Annual Review of Ecology and Systematics, 17, 137-167.

Vitousek, P.M., Walker, L.R., Whiteaker, L.D. \& Matson, P.A. (1993) Nutrient limitations to plant growth during primary succession in Hawaii Volcanoes National Park. Biogeochemistry, 23, 197-215.

Winer, B.J., Brown, D.R. \& Michels, K.M. (1991) Statistical Principles in Experimental Design, 3rd edn. McGraw Hill, New York.

Wright, S.J., Muller-Landau, H.C., Condit, R. \& Hubbell, S.P. (2003) Gapdependent recruitment, realized vital rates, and size distributions of tropical trees. Ecology, 84, 3174-3185.

Wright, S.J., Yavitt, J.B., Wurzburger, N., Turner, B.L., Tanner, E.V.J., Sayer, E.J., Santiago, L.S., Kaspari, M., Hedin, L.O., Harms, K.E., Garcia, M.N. \& Corre, M.D. (2011) Potassium, phosphorus or nitrogen limit root allocation, tree growth and litter production in a lowland tropical forest. Ecology, 92, 1616-1625.

Yavitt, J.B. \& Wright, S.J. (1996) Temporal patterns of soil nutrients in Panamanian moist forest revealed by ion-exchange resin and experimental irrigation. Plant and Soil, 183, 117-129.

Yavitt, J.B. \& Wright, S.J. (2008) Seedling growth responses to water and nutrient augmentation in the understorey of a lowland moist forest, Panama. Journal of Tropical Ecology, 24, 19-26.

Yavitt, J.B., Wright, S.J. \& Wieder, R.K. (2004) Seasonal drought and dry season irrigation influence leaf litter nutrients and soil enzymes in a moist, lowland forest in Panama. Austral Ecology, 29, 177-188.

Yavitt, J.B., Harms, K.E., Garcia, M.N., Wright, S.J., He, F. \& Mirabello, M.J. (2009) Spatial heterogeneity of soil chemical properties in a lowland tropical moist forest, Panama. Australian Journal of Soil Research, 47, 674687.

Yavitt, J.B., Harms, K.E., Garcia, M.N., Mirabello, M.J. \& Wright, S.J. (2011) Soil fertility and fine root dynamics in response to four years of nutrient (N, $\mathrm{P}, \mathrm{K}$ ) fertilization in a lowland tropical moist forest, Panama. Austral Ecology, 36, 433-445.

Received 26 January 2011; accepted 9 September 2011

Handling Editor: Frank Gilliam 